\title{
HUBUNGAN USIA, PEKERJAAN DAN PENDIDIKAN IBU DENGAN PEMBERIAN ASI EKSKLUSIF
}

\author{
Hana Rosiana Ulfah ${ }^{1}$, Farid Setyo Nugroho ${ }^{2}$ \\ ${ }^{1}$ Prodi Keperawatan S1, Prodi Kesehatan Masyarakat, Stikes Estu Utomo \\ ${ }^{2}$ Universitas Veteran Bangun Nusantara Sukoharjo \\ hana_afnan@yahoo.co.id, faridsetyo25@gmail.com
}

\begin{abstract}
Abstrak
Pendahuluan: ASI eksklusif merupakan makanan terbaik bagi bayi sampai usia 6 bulan dan dianjurkan sampai anak berusia 2 tahun dengan pemberian makanan tambahan. Berdasarkan rekapitulasi data dari Dinas Kesehatan Kabupaten Sukoharjo diperoleh data Cakupan ASI Ekslusif pada Tahun 2018 sebesar 61,04\% tertinggi di Kecamatan Tawangsari sebesar 79,0\%, Kecamatan Baki cukup rendah yaitu sebesar 50,6\% jauh dari target yaitu 80\% (Dinkes Sukoharjo, 2018). Menurut hasil survei pendahuluan di Puskesmas Kecamatan Baki didapatkan hasil bahwa cakupan ASI Ekslusif bayi usia 0-6 bulan baru mencapai $54 \%$ dari total jumlah bayi yaitu sebanyak 266 dari total jumlah bayi usia 0-6 bulan 493 .

Tujuan: Mengetahui hubungan usia, pendidikan dan pekerjaan ibu dengan pemberian ASI Eksklusif Metode: Metode penelitiaan surey analitik dengan pendekatan cross sectional. Desain penelitian merupakan penelitian observasional. Populasi dalam penelitian ini adalah ibu yang memiliki anak usia 6-24 bulan di wilayah kerja Puskesmas Kecamatan Baki Kabupaten Sukoharjo. Instrumen menggunakan kuesioner. Analisis pada penelitian ini menggunakan analisis univariat, bivariat dan multivariat

Hasil: Hasil analisis bivariat menunjukkan bahwa tidak ada hubungan signifikan antara usia ibu dengan pemberian ASI eksklusif dengan $\mathrm{p}>0,05(0,413)$, pendidikan ibu dengan pemberian ASI eksklusif dengan $\mathrm{p}>0,05(0,382)$. Sedangkan pada variabel pekerjaan ibu mempunyai hubungan yang signifikan dengan pemberian ASI eksklusif dengan $\mathrm{p}<0,05(0,028)$. Hasil analisis multivariat menunjukkan tidak adanya hubungan bersama-sama antara usia, pendidikan dan pekerjaan ibu dengan pemberian ASI eksklusif dengan $\mathrm{p}>0,05(0,61)$.
\end{abstract}

Kesimpulan: Pekerjaan ibu menjadi faktor yang lebih mempengaruhi pada pemberian ASI dibandingkan dengan faktor usia maupun pendidikan ibu.

Kata kunci : ASI eksklusif, Usia ibu, Pendidikan ibu, Pekerjaan ibu.

\begin{abstract}
Introduction: Exclusive breastfeeding is the best food for infants up to 6 months of age and is recommended until children are 2 years old with supplementary feeding. Based on recapitulation of data from the Sukoharjo District Health Office, the highest exclusive breastfeeding data in 2018 was 61.04\% in Tawangsari Subdistrict with 79.0\%, Baki Subdistrict was quite low at 50.6\%, far from the target of $80 \%$ (DHO Sukoharjo, 2018). According to preliminary survey results at the Baki District Health Center, it was found that the coverage of exclusive breastfeeding for infants aged 0-6 months reached 54\% of the total number of infants, totaling 266 of the total infants aged 0-6 months 493.

Objective: To determine the relationship of age, education and occupation of mothers with exclusive breastfeeding

Method: Surey analytic research method with cross sectional approach. The study design is an observational study. The population in this study is mothers who have children aged 6-24 months in the working area of the Baki District Health Center, Sukoharjo Regency. The instrument uses a questionnaire. The analysis in this study uses univariate, bivariate and multivariate analysis

Results: The results of bivariate analysis showed that there was no significant relationship between maternal age with exclusive breastfeeding with $p>0.05$ (0.413), maternal education with exclusive breastfeeding with $p>0.05$ (0.382). While the mother's occupation variable has a significant
\end{abstract}


relationship with exclusive breastfeeding with $p<0.05$ (0.028). The results of multivariate analysis showed no joint relationship between age, education and occupation of mothers with exclusive breastfeeding with $p>0.05(0.61)$.

Conclusion: Mother's work is a more influential factor in breastfeeding compared to age and mother's education.

Keywords: exclusive breastfeeding, mother's age, mother's education, mother's occupation.

\section{Pendahuluan}

Air Susu Ibu (ASI) merupakan makanan terbaik untuk bayi yang mengandung sel darah putih, protein dan zat kekebalan yang cocok untuk bayi. Presentase pemberian ASI Ekslusif pada bayi 0-6 bulan di Jawa Tengah pada tahun 2017 sebesar 54,4\%, sedikit meningkat jika dibandingkan presentase pemberian ASI Ekslusif tahun 2016 yaitu 54,2\%. Pemberian ASI Ekslusif di Kabupaten Sukoharjo pada tahun 2017 terbilang cukup rendah sebesar $41 \%$. Tertinggi di Kabupaten Magelang sebesar 87,2\% dengan cakupan target $81 \%$ (Dinkes Jawa Tengah, 2017).

Berdasarkan hasil survei pendahuluan yang dilakukan di Puskesmas Kecamatan Baki pada bulan Mei 2019 dengan metode wawancara kepada petugas gizi didapatkan hasil untuk cakupan ASI Ekslusif bayi usia 0-6 bulan sebesar 266 dari total jumlah bayi usia 0-6 bulan 493.

Penelitian serupa dilakukan di daerah lain hanya menganalisis tentang univariat dan bivariatnya. Namun dalam penelitian ini menganalisis secara multivariat juga.Yang mana pada analisis multivariat dapat mencari pengaruh tiga variabel yaitu usia, pendidikan serta pekerjaan terhadap pemberian ASI eksklusif secara serentak.

Tujuan penelitian ini untuk mengetahui hubungan usia, pendidikan dan pekerjaan ibu dengan pemberian ASI Eksklusif.

\section{Metode Penelitian}

Metode penelitiaan menggunakan surey analitik dengan pendekatan cross sectional.Desainpenelitian merupakan penelitian observasional, data yang diperoleh dilakukan analisis deskriptif dan analitik.Tempat penelitian diWilayah Kerja Puskesmas Kecamatan Baki, Sukoharjo, Jawa Tengah. Waktu penelitian padaBulan Juli 2019.

Populasi dalam penelitian ini adalah ibu yang memiliki anak usia 6-24 bulan di wilayah kerja Puskesmas Kecamatan Baki Kabupaten Sukoharjo. Jumlah populasi ibu yang memiliki anak usia 6-24 bulan di wilayah kerja Puskesmas Kecamatan Baki yaitu sebanyak 1.446 orang. Data diperoleh dari sistem informasi manajemen puskesmas Gizi kesehatan ibu dan anak (Simpus Gizi KIA). Sampel dalam penelitian ini adalah ibu yang mempunyai anak 
berusia 6-24 bulan, yang diperoleh berdasarkan rumus Slovin yang berjumlah 94 responden.Sampel dalam penelitian ini diambil dengan menggunakan teknik Accidental Sampling.

Data primer dalam penelitian ini diperoleh secara langsung dari responden melalui wawancara terstruktur menggunakan kuesioner mengenai karakteristik umur, pekerjaan, pendidikan dan pemberian ASI eksklusif. Sebelum wawancara, responden mengisi lembar informed consent. Data sekunder dalam penelitian ini merupakan data penunjang kelengkapan data primer. Data diperoleh dari Puskesmas Baki Kecamatan Baki Kabupaten Sukoharjo dan referensi lainnya yang terkait dengan penelitian.

Analisis pada penelitian ini menggunakan analisis univariat, bivariat dan multivariat. Analisis univariat terkait karakteristik responden meliputi usia, pendidikan dan pekerjaan.Analisis bivariat dilakukan terhadap dua variabel yang diduga berhubungan atau berkorelasi yaitu hubungan antarausia ibu dengan pemberian ASI eksklusif, pendidikan ibu dengan pemberian ASI eksklusif, dan pekerjaan ibu dengan pemberian ASI eksklusif. Analisis multivariat dilakukan untuk mengetahui pengaruh secara serentak antara usia, pendidikan dan pekerjaan ibu dengan pemberian ASI eksklusif.

\section{Hasil}

\section{Analisis Univariat}

a. Karakteristik

1) Umur Responden

Distribusi hasil penelitian mengenai umur responden di wilayah kerja Puskesmas Kecamatan Baki, sebagai berikut :

Tabel 1. Distribusi Umur Responden

\begin{tabular}{ccc}
\hline Umur Ibu & $\mathbf{N}$ & $\mathbf{( \% )}$ \\
\hline$<20$ Tahun & 1 & 1,1 \\
20-35 Tahun & 78 & 83,0 \\
$\geq 35$ Tahun & 15 & 16,0 \\
Total & 94 & 100 \\
\hline Berdasarkan tabel 1 diketahui bahwa umur responden di wilayah kerja
\end{tabular}

Puskesmas Kecamatan Baki Kabupaten Sukoharjo terbanyak adalah kategori 20-35 tahun sebanyak 78 orang $(83,0 \%)$.

2) Pendidikan Responden

Distribusi hasil penelitian mengenai pendidikan responden di wilayah kerja Puskesmas Kecamatan Baki, sebagai berikut : 
Tabel 2. Distribusi Pendidikan Responden

\begin{tabular}{ccc}
\hline Pendidikan & N & $(\mathbf{\% )}$ \\
\hline Tidak Tamat SD & 1 & 1,1 \\
Tamat SD & 5 & 5,3 \\
Tamat SMP & 27 & 28,7 \\
Tamat SMA & 41 & 43,6 \\
Perguruan Tinggi & 20 & 21,3 \\
Total & 94 & 100 \\
\hline Berdasarkan tabel 6 diketahui bahwa Pendidikan responden & terbanyak di
\end{tabular}
wilayah kerja Puskesmas Kecamatan Baki Kabupaten Sukoharjo adalah Tamat SMA sebanyak 41 orang $(43,6 \%)$.

3) Pekerjaan Responden

Distribusi hasil penelitian mengenai Pekerjaan responden di wilayah kerja Puskesmas Kecamatan Baki, sebagai berikut :

Tabel 3. Distribusi Pekerjaan Responden

\begin{tabular}{ccc}
\hline Pekerjaan & N & $(\boldsymbol{\%})$ \\
\hline PNS & 3 & 3,2 \\
Pegawai Swasta & 24 & 25,5 \\
Wiraswasta & 17 & 18,1 \\
IRT & 41 & 43,6 \\
Buruh & 9 & 9,6 \\
Total & 94 & 100 \\
\hline
\end{tabular}

Berdasarkan tabel 3 diketahui bahwa Pekerjaan responden terbanyak di wilayah kerja Puskesmas Kecamatan Baki Kabupaten Sukoharjo adalah IRT sebanyak 41 orang $(43,6 \%)$.

4) Pemberian ASI Eksklusif

Distribusi pemberian ASI Eksklusif di wilayah kerja Puskesmas Kecamatan Baki, yaitu sebagai berikut :

Tabel 4. Distribusi Pemberian ASI Eksklusif

\begin{tabular}{ccc}
\hline Pemberian ASI Ekslusif & N & $(\boldsymbol{\%})$ \\
\hline ASI Ekslusif & 36 & 38,3 \\
Tidak ASI Ekslusif & 58 & 61,7 \\
Total & 94 & 100 \\
\hline
\end{tabular}

Berdasarkan tabel 4 diketahui bahwa mayoritas ibu tidak memberikan ASI

eksklusif yaitu sebesar $61,7 \%$ atau 58 responden dari total 100 responden.

\section{Analisis Bivariat}

a. Analisis hubungan antara usia ibu dengan pemberian ASI eksklusif

Data hasil uji Chi Square dari data penelitian tentang hubungan antara usia ibu dengan pemberian ASI Ekslusif di wilayah kerja Puskesmas Kecamatan Baki, sebagai berikut : 
Tabel 5. Analisis Hubungan antara Usia Ibu dengan Pemberian ASI Ekslusif

\begin{tabular}{|c|c|c|c|c|c|c|c|}
\hline \multirow{3}{*}{ Usia Ibu } & \multicolumn{4}{|c|}{ Pemberian ASI Ekslusif } & \multicolumn{2}{|c|}{ Total } & \multirow[t]{3}{*}{ p value } \\
\hline & \multicolumn{2}{|c|}{$\mathbf{Y a}$} & \multicolumn{2}{|c|}{ Tidak } & & & \\
\hline & $\mathbf{N}$ & $\%$ & $\mathbf{N}$ & $\%$ & $\mathbf{N}$ & $\%$ & \\
\hline$<20$ & 1 & 1,06 & 0 & 0 & 1 & 1,06 & \\
\hline $20-35$ & 30 & 31,92 & 48 & 51,06 & 78 & 82,98 & 0,413 \\
\hline$>35$ & 5 & 5,32 & 10 & 10,64 & 15 & 15,96 & \\
\hline & & & & & 94 & 100 & \\
\hline
\end{tabular}

Berdasarkan tabel 5 hasil uji Chi Square diperoleh nilai p value sebesar 0,413 >

0,05 dapat disimpulkan bahwa tidak ada hubungan antara usia ibu dengan pemberian ASI ekslusif.

b. Analisis hubungan antara pendidikan ibu dengan pemberian ASI eksklusif

Data hasil uji Chi Squaredari data penelitian tentang hubungan antara pendidikan ibu dengan pemberian ASI Ekslusif di wilayah kerja Puskesmas Kecamatan Baki, sebagai berikut :

Tabel 6. Analisis Hubungan antara pendidikan Ibu dengan Pemberian ASI Ekslusif

\begin{tabular}{|c|c|c|c|c|c|c|c|}
\hline \multirow{3}{*}{ Pendidikan Ibu } & \multicolumn{4}{|c|}{ Pemberian ASI Ekslusif } & \multirow{2}{*}{\multicolumn{2}{|c|}{ Total }} & \multirow[t]{3}{*}{ p value } \\
\hline & \multicolumn{2}{|c|}{$\mathbf{Y a}$} & \multicolumn{2}{|c|}{ Tidak } & & & \\
\hline & $\mathbf{N}$ & $\%$ & $\mathbf{N}$ & $\%$ & $\mathbf{N}$ & $\%$ & \\
\hline Tidak tamat SD & 0 & 0 & 1 & 0 & 1 & 1,06 & \\
\hline Tamat SD & 0 & 0 & 5 & 5,32 & 5 & 5,32 & 0,382 \\
\hline Tamat SMP & 11 & 11,7 & 16 & 17 & 27 & 28,7 & \\
\hline Tamat SMA & 16 & 17 & 25 & 26,6 & 41 & 43,6 & \\
\hline Perguruan Tinggi & 9 & 9,57 & 11 & 11,7 & 20 & 21,27 & \\
\hline & & & & & 94 & 100 & \\
\hline
\end{tabular}

0,05 dapat disimpulkan bahwa tidak ada hubungan antara pendidikan ibu dengan pemberian ASI ekslusif.

c. Analisis hubungan antara pekerjaan ibu dengan pemberian ASI eksklusif

Data hasil uji Chi Squaredari data penelitian tentang hubungan antara pekerjaan ibu dengan pemberian ASI Ekslusif di wilayah kerja Puskesmas Kecamatan Baki, sebagai berikut : 
Tabel 7. Analisis Hubungan antara pekerjaan Ibu dengan Pemberian ASI Ekslusif

\begin{tabular}{|c|c|c|c|c|c|c|c|}
\hline \multirow{3}{*}{ Pekerjaan Ibu } & \multicolumn{4}{|c|}{ Pemberian ASI Ekslusif } & \multirow{2}{*}{\multicolumn{2}{|c|}{ Total }} & \multirow[t]{3}{*}{ p value } \\
\hline & \multicolumn{2}{|c|}{ Ya } & \multicolumn{2}{|c|}{ Tidak } & & & \\
\hline & $\mathbf{N}$ & $\%$ & $\mathbf{N}$ & $\%$ & $\mathbf{N}$ & $\%$ & \\
\hline PNS & 2 & 2,1 & 1 & 1,06 & 3 & 3,16 & \\
\hline Pegawai Swasta & 4 & 4,3 & 20 & 21,3 & 24 & 25,6 & 0,028 \\
\hline Wiraswasta & 11 & 11,7 & 6 & 6,4 & 17 & 18,08 & \\
\hline IRT & 16 & 17 & 25 & 26,6 & 41 & 43,6 & \\
\hline \multirow[t]{2}{*}{ Buruh } & 3 & 3,2 & 6 & 6,4 & 9 & 9,6 & \\
\hline & & & & & 94 & 100 & \\
\hline
\end{tabular}

Berdasarkan tabel 7 hasil uji Chi Square diperoleh nilai p value sebesar 0,028 <

0,05 dapat disimpulkan bahwa ada hubunganyang signifikan antara pekerjaan ibu dengan pemberian ASI ekslusif.

\section{Analisis Multivariat}

Beberapa variabel bebas yaitu variabel usia ibu, pendidikan ibu dan pekerjaan ibu yang berhubungan dengan variabel terikat yaitu pemberian ASI eksklusif secara bersamasama di analisis dalam perhitungan uji regresi logistik dengan hasil sebagai berikut :

Tabel 8. Pengaruh Variabel Usia, Pendidikan dan Pekerjaan Ibu dengan Pemberian ASI Ekslusif

\begin{tabular}{cccc}
\hline Variabel Bebas & B & Wald & Sig \\
\hline Usia Ibu & 0,177 & 0,064 & 0,801 \\
Pendidikan Ibu & 0,854 & 4,729 & 0,030 \\
Pekerjaan Ibu & 0,642 & 4,460 & 0,035 \\
\hline
\end{tabular}

Tabel 8 menunjukkan pengaruh bersama-sama variabel bebas terhadap variabel terikat. Hasil analisis menunjukkan bahwa ada dua variabel yang $\mathrm{p}$-valuenya $<0,05$, sehingga dapat diambil kesimpulan bahwa variabel pendidikan dan pekerjaan ibu mempunyai pengaruh terhadap pemberian ASI eksklusif.

\section{Pembahasan}

\section{Analisis Univariat}

Usia responden dalam penelitian ini antara 20-35 tahun yakni sebanyak 78 orang $(83,0 \%)$. Usia 20-35 tahun merupakan usia aman yang dianjurkan untuk kehamilan, persalinan dan menyusui (BKKBN, 2009). Ibu dengan usia kurang dari 20 tahun memiliki fisik, mental dan psikologi yang belum matang saat menghadapi kehamilan, persalinan dan pemberian ASI. Sedangkan ibu dengan usia lebih dari 35 tahun memiliki fisik dan alat reproduksi yang sudah berkurang dan menurun secara fungsi sehingga akan menimbulkan resiko bawaan pada bayi ataupun kesulitan ibu saat kehamilan (Hidajati, 2012). 
Kategori pendidikan responden dapat diketahui bahwa responden dengan tingkat pendidikan SMA sebanyak 41 orang $(43,6 \%)$ dantidak tamat SD 1 orang $(1,1 \%)$. Menurut Notoatmodjo (2010),salah satu faktor yang mempengaruhi pengetahuan adalah pendidikan. Semakin tinggi pendidikan maka semakin baik pengetahuannya. Hal ini sesuai dengan hasil penelitian Hartini (2014) bahwa ada hubungan yang signifikan antara tingkat pendidikan ibu dengan keberhasilan ASI eksklusif pada bayi usia 6-12 bulan di Puskesmas Kasihan II Yogyakarta.

Pada karakteristik pekerjaan didapatkan hasil bahwa sebagian besar responden adalah ibu rumah tangga (IRT) yakni sebanyak 41 orang $(43,6 \%)$. Bagi ibu, bekerja akan mempunyai pengaruh terhadap kehidupan keluarga (Wawan dan Dewi, 2010). Hal ini berpengaruh dalam pemberian ASI eksklusif,IRT banyak yang memberikan ASI eksklusif pada bayinya, karena ibu rumah tangga memiliki banyak waktu dan kesempatan yang banyak bersama bayinya, sehingga dapat memberikan ASI secara eksklusif pada bayinya dari pada ibu yang bekerja.

\section{Analisis Bivariat}

a. Hubungan antara usia ibu dengan pemberian ASI eksklusif

Hasil analisis dengan uji Chi Square dengan nilai p-value 0,413 yang menunjukkan bahwa tidak ada hubungan yang signifikan antara usia ibu dengan pemberian ASI eksklusif. Sedangkan menurut Wawan dan Dewi (2010) semakin cukup umur tingkat kematangan dan kekuatan seseorang berpikir dan bekerja akan lebih baik. Hal ini sesuai dengan hasil penelitian Conita (2014) bahwa terdapat pengaruh antara usia ibu dengan pemberian ASI eksklusif.

Pada penelitian ini, rendahnya keberhasilan ASI eksklusif dapat disebabkan karena berbagai faktor salah satunya adalah dukungan suami seperti hasil penelitian Prayogo, Deni (2013) bahwa ada hubungan antara dukungan suami dengan pemberian ASI eksklusif. Faktor lain yaitu responden dengan usia lebih dari 30 tahun memiliki lebih banyak anak yang mana pengalaman sebelumnya menunjukkan bahwa anak yang tidak diberikan ASI eksklusif dan anaknya tetap sehat sehingga mempengaruhi perilaku menyusui saat ini (Oselaguri, 2012).

b. Hubungan antara pendidikan ibu dengan pemberian ASI eksklusif

Hasil pada analisis dengan uji Chi Square menunjukkan p-value 0,382 sehingga dapat disimpulkan bahwa tidak ada hubungan antara pendidikan ibu dengan pemberian 
ASI eksklusif. Namun karakteristik responden dengan tingkat pendidikan SMA lebih banyak dalam pemberian ASI eksklusif daripada responden dengan tingkat pendidikan SD. Menurut Notoatmodjo (2010) menjelaskan bahwa semakin tinggi pendidikan maka semakin mudah menerima hal-hal baru dan lebih mudah menyesuaikan diri dengan hal baru tersebut.

c. Hubungan antara pekerjaan ibu dengan pemberian ASI eksklusif

Hasil penelitian menunjukkan p-value 0,028 yang berarti bahwa ada hubungan yang signifikan antara pekerjaan ibu dengan pemberian ASI eksklusif.Hal ini sejalan dengan hasil penelitian Bahriyah (2017) menyatakan bahwa ada hubungan yang signifikan antara pekerjaan ibu dengan pemberian ASI eksklusif dengan p-value 0,018.

Menurut penelitian Conita (2014) pekerjaan ibu erat kaitannya dengan keberhasilan pemberian ASI eksklusif. Pada hasil penelitian menunjukkan bahwa dari total ibu yang memberikan ASI eksklusif adalah ibu yang bekerja yaitu 20 responden, sedangkan IRT sebanyak 16 responden. Sedangkan $53 \%$ responden adalah ibu bekerja dan $47 \%$ sisanya adalah IRT.Hal ini menunjukkan distribusi yang merata antara ibu bekerja maupun IRT.

Menurut Rotinsulu, dkk (2012) menyebutkan bahwa semakin baik pengetahuan ibu tentang ASI eksklusif maka semakin tinggi angka keberhasilan ibu dalam pemberian ASI eksklusif pada bayinya. Hal ini selaras dengan hasil penelitian bahwa pemberian ASI eksklusif pada ibu bekerja memiliki prevalensi yang tinggi karena menurut penelitian Okawary (2015) menyebutkan bahwa ibu yang bekerja cenderung memiliki pendidikan tinggi mengingat bahwa kesempatan bekerja lebih banyak bagi orang dengan pendidikan tinggi.

Sedangkan pada penelitian Hartini (2014) menunjukkan bahwa IRT memiliki peluang keberhasilan dalam pemberian ASI eksklusif karena IRT mempunyai waktu yang lebih banyak bersama bayinya. Namun pada hasil penelitian ini menunjukkan bahwa 25 ibu dari 41 total IRT tidak memberikan ASI eksklusif pada bayinya. Hal ini dikarenakan pengetahuan ibu yang kurang tentang ASI eksklusif.

\section{Analisis Multivariat}

Hasil analisis multivariat menunjukkan bahwa tidak ada pengaruh bersamaan antara usia, pendidikan dan pekerjaan ibu dengan pemberian ASI eksklusif. Namun nilai p-value pada variabel pendidikan dan pekerjaan mempunyai pengaruh yang signifikan terhadap pemberian ASI eksklusif. Hal ini sesuai dengan penelitian Okawary (2015) bahwa ibu yang 
mempunyai pendidikan tinggi cenderung memiliki rasa ingin tahu yang lebih tinggi terhadap tumbuh kembang bayinya. Sedangkan ibu yang bekerja cenderung memiliki pendidikan yang lebih tinggi mengingat kesempatan bekerja pada orang dengan pendidikan tinggi lebih banyak daripada yang berpendidikan rendah.

\section{Kesimpulan}

Hasil pada penelitian menunjukkan tidak ada hubungan antara usia dan pendidikan ibu dengan pemberian ASI eksklusif.Ada hubungan yang signifikan antara pekerjaan ibu dengan pemberian ASI eksklusif. Sedangkan pada analisis multivariate menunjukkan tidak ada pengaruh secara serentak antara usia, pendidikan dan pekerjaan ibu dengan pemberian ASI eksklusif.

\section{Saran}

Untuk peneliti selanjutnya dapat meneliti tentang pengetahuan manajemen pemberian ASI eksklusif pada Ibu bekerja.

\section{Daftar Pustaka}

Bahriyah, F., Putri, M., Jaelani, A.K., 2017. Hubungan Pekerjaan Ibu Terhadap Pemberian ASI Eksklusif pada Bayi. Jurnal Endurance Vol 2 No 2. Diakses tanggal 23 Oktober 2019. http://doi.org/10.22216/jen.v2i2.1699.

BKKBN. 2009. Keluarga Berencana Dan Kesehatan Reproduksi Kebijakan, Program dan Kegiatan. Jakarta: BKKBN

Conita, D.A (2014). Perbedaan Pertumbuhan Bayi Usia 3-6 Bulan yang Diberi ASI Eksklusif dan yang Tidak Diberi ASI Eksklusif di Puskesmas Gang Sehat Kecamatan Pontianak Selatan Tahun 2014. Jurnal Mahasiswa PSPD FK Universitas Tanjungpura Vol 1 No $\begin{array}{lllll}1 . & \text { Diakses } & \text { tanggal } & 8 & \text { November }\end{array}$ http://jurnal.untan.ac.id/index.php/jfk/article/download/5495/5669

Dinkes Sukoharjo, 2018. Profil Kesehatan Kabupaten Sukoharjo. Sukoharjo: Dinkes Kabupaten Sukoharjo.

Hartini, Susi. 2014. Hubungan Tingkat Pendidikan Ibu dengan Keberhasilan ASI Eksklusif pada Bayi Umur 6-12 Bulan di Puskesmas Kasihan II Yogyakarta. Skripsi. Stikes Aisyiyah Yogyakarta. Diakses tanggal 20 November 2019.http://digilib.unisayogya.ac.id/1249/1/SUSI\%20HARTINI_201310104375_NA SKAH\%20PUBLIKASI.pdf.

Hidajati, A. 2012. Mengapa Seorang Ibu Harus Menyusui?. Yogyakarta: Flashbook 
Notoatmodjo, S. 2010. Metodologi Penelitian Pengetahuan, Sikap, dan Perilaku Manusia. Yogayakarta: Nuha Medika.

Okawary, O., 2015. Hubungan Status Pekerjaan Ibu Dengan Pemberian Asi Eksklusif Di Wilayah Kerja Puskesmas Seyegan Sleman Yogyakarta. Skripsi. Sekolah Tinggi Ilmu Kesehatan 'Aisyiyah, Yogyakarta. http://digilib.unisayogya.ac.id/199/1/naskah\%20publikasi\%20ory\%20okawary.pdf

Oselaguri, 2015. Faktor-Faktor yang Berhubungan dengan Pemberian ASI Eksklusif di Wilayah Kerja Puskesmas Sewon II Kecamatan Sewon, Kabupaten Bantul Yogyakarta Tahun 2012.Diakses tanggal 21 Oktober 2019.http://digilib.unisayogya.ac.id/1514/1/NASKAH\%20PUBLIKAS.pdf.

Prayogo, D. 2013. Hubungan Peran Bidan dan Dukungan Suami dengan Pemberian ASI Ekslusif di Wilayah Kerja Puskesmas Colomadu 1. Skripsi Ilmiah. Surakarta: Universitas Muhammadiyah

Rotinsulu, S.R., Pelealu, F.J.O., Tucunan, A., 2012. Relationship Between Knowledge And Work of Mothers With Exclusive Breastfeeding In The Work Area Of Puskesmas (Health Center) Remboken Sub-District Remboken Minahasa. Fakultas Kesehatan Masyarakat Universitas Sam Ratulangi, Manado.

Wawan, A., Dewi, M. 2010. Teori dan Pengukuran Pengetahuan dan Sikap dan Perilaku Manusia. Yogyakarta: Nuha Medika 